\title{
Elucidation on Reactions Thermodynamics and Kinetics of OFC-A of Steels
}

\author{
A.V. Adedayo ${ }^{1,2}$ \\ ${ }^{1}$ Department of Metallurgical Engineering, Kwara State Polytechnic, Ilorin, Nigeria \\ ${ }^{2}$ Materials Science and Engineering Department, Obafemi Awolowo University, Ile-Ife, \\ Nigeria \\ E-Mail: adelekeadedayo58@yahoo.com
}

\begin{abstract}
The basic principles of Oxyfuel cutting of metals lie in rapid high-temperature oxidation of the cut metal. Considerable proportion of the published work on the subject of oxygen cutting, the details of the oxidation reaction are overlooked or confused. Most often, physical characteristics of oxidized material is attributed to that of iron rather than iron oxide. The analysis of the oxidation reactions pertinent to Oxyfuel cutting of steels has also been majorly ignored. The oxidation process of iron and steel though similar in some respects, yet, in other aspects, show significant differences. This paper presents experimental and theoretical elucidation on reactions thermodynamics and kinetics of oxyfuel cutting processes of steel. Six $10 \mathrm{~mm}$ metallurgy steel rods of different wt\% $C$ were flame cut using different acetylene and oxygen pressures. The composition of the steel rods used ranged from $0.16 \mathrm{wt} \% \mathrm{C}$ to $0.33 w t \%$ C. Acetylene pressures used ranged from $3.45 \times 10^{-2} \mathrm{~N} . \mathrm{m}^{-2}$ to $5.52 \times 10^{-2} \mathrm{~N} . \mathrm{m}^{-2}$, while oxygen pressure ranged from $2.76 \times 10^{-1} \mathrm{~N} . \mathrm{m}^{-2}$ to $3.17 \times 10^{-1} \mathrm{~N} . \mathrm{m}^{-2}$. The result shows that the cutting rates decreased with carbon content of the steel as a result of reduction of iron oxide during decarburization reactions. Theoretical models of the thermodynamics and kinetics of cutting process pertinent to steels are also discussed.
\end{abstract}

Keywords: Flame cutting, Oxyfuel, Oxyacetylene, Steel oxidation, Decarburization.

\section{INTRODUCTION}

OFC-A is American Welding Society (AWS) classification for oxyfuel gas cutting in which acetylene is the fuel [1]. Oxy-fuel cutting are processes that use fuel gases and oxygen to cut metals. French engineers Edmond Fouche and Charles Picard became the first to develop an oxygen-acetylene machine in 1903. 
Oxy-fuel is one of the oldest welding processes, however, it is still widely used for welding pipes and tubes, as well as repair work. In the developing worlds where incesant power outage is a common phenomeneon, OFC has made arc-welding/cutting unlucrative. It is also frequently well-suited, and favored, for fabricating some types of metal-based artwork. Oxyfuel equipment is versatile, lending itself not only to some sorts of iron or steel welding but also to brazing, braze-welding, metal heating (for bending and forming), and also oxyfuel cutting. The low cost of OFC-A equipment is one of the main reasons for its use. In oxy-fuel cutting (OFC), a cutting torch is used to heat metal to kindling temperature where the metal starts to turn a cherry red. A stream of oxygen then trained on the metal combines with the metal which then flows out as an oxide slag to creat the kerf [1-3] .The cut quality depends on the torch tip size, type, and distance from the metal [1], the oxygen and preheat gas flow rates and the cutting speed. However, the kinetics of the process will also depend on the oxidation process of the cut metal.

The basic principles of Oxyfuel cutting (OFC-A) of metals, lie in rapid high-temperature oxidation of the cut metal. Considerable proportion of the published work on the subject of oxygen cutting, the details of the oxidation reaction are overlooked or confused [4]. For example, it is not uncommon for the oxidized material to be attributed with the physical characteristics of iron rather than iron oxide. The iron oxide produced as a result of oxidation by OFC-A is not clear-cut elucidated. DeGarmo [3] believes $\mathrm{Fe}_{3} \mathrm{O}_{4}$ is formed. Masachuesset Institute of Technology [5] identifies $\mathrm{FeO}, \mathrm{Fe}_{2} \mathrm{O}_{3}$, and $\mathrm{Fe}_{3} \mathrm{O}_{4}$ as potential oxides that could be produced. The analysis of the oxidation reactions pertinent to OFC-A of steels has, also been majorly ignored. The focus of most literature has been on the Fe content of the ferrous alloy, while the other contents are ignored. The oxidation process of iron and steel though similar in some respects, yet, in other aspects, show significant differences. A practical example of this is found during the construction of the steel skeleton for a flour mill in Nigeria in 2006. It was planned that the period of execution of the job would be 6 months, based on the understanding that mild steel $(0.16 \mathrm{w} \% \mathrm{C})$ would be used for the steel skeleton. The cost of the project should be N15.23 million. However, the client purchased medium carbon steel $(0.33 \mathrm{wt} \% \mathrm{C})$. The result was that the rate of job execution was much slower than expected. The job would require about 14 months. Also more volumes of oxyfuel gases are required. The cost for labour, accommodation, feeding, transport, and rented equipments had doubled. Generally, cost became very high and over N13 million have to be added to initial N15.23 million. Definitely, there was problem. The client believed this was a gimmick by the contractor to siphon fund. The client believed $0.33 \mathrm{wt} \% \mathrm{C}$ steel should cut faster since it has a lower melting point.

In this present paper, a description of the mechanism of interactions of the different phases involved in the reactions of slag forming process when steel is cut is provided. The role of carbon in this process is elucidated. Theoretical models of the thermodynamics and kinetics of cutting process pertinent to steels are also discussed. Similar theoretical models have been applied in laser-oxygen assisted cutting [6-15]. 


\section{METHODOLOGY}

The hot-rolled $10 \mathrm{~mm}$ metallurgy steel rods that were used in this study were procured from the Universal Steel Rolling Mill, Ogba-Ikeja, Lagos, Nigeria. These were cut into $0.2 \mathrm{~m}$ long specimen. The compositions of the steel rods are given in Table 1.

Table 1: Composition of steels used.

\begin{tabular}{|l|l|l|l|l|l|l|l|l|l|l|l|}
\hline SN & \multicolumn{1}{|l}{ Alloying elements (wt\%) } \\
\hline & $\mathrm{C}$ & $\mathrm{Si}$ & $\mathrm{S}$ & $\mathrm{P}$ & $\mathrm{Mn}$ & $\mathrm{Ni}$ & $\mathrm{Cr}$ & Mo & $\mathrm{V}$ & $\mathrm{W}$ & Fe \\
\hline 1. & 0.16 & 0.18 & 0.0589 & 0.0288 & 0.6440 & 0.1030 & 0.1244 & 0.0114 & 0.0010 & 0.0007 & Rest \\
\hline 2. & 0.18 & 0.22 & 0.0410 & 0.0237 & 0.7160 & 0.1100 & 0.1250 & 0.0220 & 0.0020 & 0.0030 & Rest \\
\hline 3. & 0.25 & 0.15 & 0.0510 & 0.0419 & 0.3658 & 0.01034 & 0.0889 & 0.0177 & 0.0003 & 0.0032 & Rest \\
\hline 4. & 0.28 & 0.18 & 0.0523 & 0.0275 & 0.6247 & 0.1170 & 0.1306 & 0.0141 & 0.0013 & 0.0035 & Rest \\
\hline 5. & 0.32 & 0.18 & 0.0576 & 0.0367 & 0.6494 & 0.01064 & 0.1550 & 0.0141 & 0.0024 & 0.0037 & Rest \\
\hline 6. & 0.33 & 0.31 & 0.052 & 0.0274 & 0.7523 & 0.1110 & 0.1750 & 0.0170 & 0.0030 & 0.0040 & Rest \\
\hline
\end{tabular}

At the required pressures, cutting torch is used to heat the steel rods surface to kindling temperature where the steel rods starts to turn a cherry red. Oxygen is then released by depressing the oxygen lever to react with the metal which then flows out of the cut (kerf) as an oxide slag. The time taken to cut the rods is noted and recorded using a stop watch. The cutting rate is calculated by finding the ratio of the diameter of rod to the total time taken i.e.:

Cutting rate $=$ Diameter of rod $/$ total time of cut

\section{RESULTS AND DISCUSSION}

Figures 1, 2, 3 and 4 show the variations of cutting rates with carbon contents at different acetylene and oxygen pressures. From Fig. 1, the cutting rate was a maximum of 2.02 $\mathrm{mm} / \mathrm{min}$ at $5.52 \times 10^{-2} \mathrm{~N} . \mathrm{m}^{-2}$ acetylene pressure and $3.17 \times 10^{-1} \mathrm{~N} . \mathrm{m}^{-2}$ oxygen pressure. A minimum of $1.02 \mathrm{~mm} / \mathrm{min}$. was achieved at $5.52 \times 10^{-2} \mathrm{~N} . \mathrm{m}^{-2}$ acetylene pressure and $2.76 \mathrm{x}$ $10^{-1} \mathrm{~N} . \mathrm{m}^{-2}$ oxygen pressure. In Fig. 2, a maximum of $1.90 \mathrm{~mm} / \mathrm{min}$ was achieved at $4.83 \times 10^{-}$ ${ }^{2} \mathrm{~N} . \mathrm{m}^{-2}$ acetylene pressure and $3.17 \times 10^{-1} \mathrm{~N} . \mathrm{m}^{-2}$ oxygen pressure for $0.16 \mathrm{wt} \% \mathrm{C}$ steel. The minimum of $0.91 \mathrm{~mm} / \mathrm{min}$ was achieved for $0.33 \mathrm{wt} \% \mathrm{C}$ steel at $4.83 \times 10^{-2} \mathrm{~N} \cdot \mathrm{m}^{-2}$ acetylene pressure and $2.76 \times 10^{-1} \mathrm{~N} . \mathrm{m}^{-2}$ oxygen pressure. Figure 3 shows that the maximum cutting rate is $1.82 \mathrm{~mm} / \mathrm{min}$ for $0.16 \mathrm{wt} \% \mathrm{C}$ steel at $4.14 \times 10^{-2} \mathrm{~N} \cdot \mathrm{m}^{-2}$ acetylene and $3.17 \times 10^{-1} \mathrm{~N} . \mathrm{m}^{-2}$ oxygen pressure. The minimum is $0.80 \mathrm{~mm} / \mathrm{min}$ for $0.33 \mathrm{wt} \% \mathrm{C}$ steel at $4.14 \times 10^{-2} \mathrm{~N} . \mathrm{m}^{-2}$ acetylene pressure and $2.76 \times 10^{-1} \mathrm{~N} \cdot \mathrm{m}^{-2}$ oxygen pressure. Figure 4 has maximum cutting rate of $1.70 \mathrm{~mm} / \mathrm{min}$. at $3.45 \times 10^{-2} \mathrm{~N} . \mathrm{m}^{-2}$ acetylene pressure for $0.16 \mathrm{wt} \% \mathrm{C}$ steel. The minimum of $0.70 \mathrm{~mm} / \mathrm{min}$. was achieved at $0.33 \mathrm{wt} \% \mathrm{C}$ steel at $3.45 \times 10^{-2} \mathrm{~N} . \mathrm{m}^{-2}$ acetylene and $2.76 \mathrm{x}$ 
$10^{-1} \mathrm{~N} . \mathrm{m}^{-2}$ oxygen pressure. Generally, the trend shows a decrease in cutting rates with increase in carbon content.

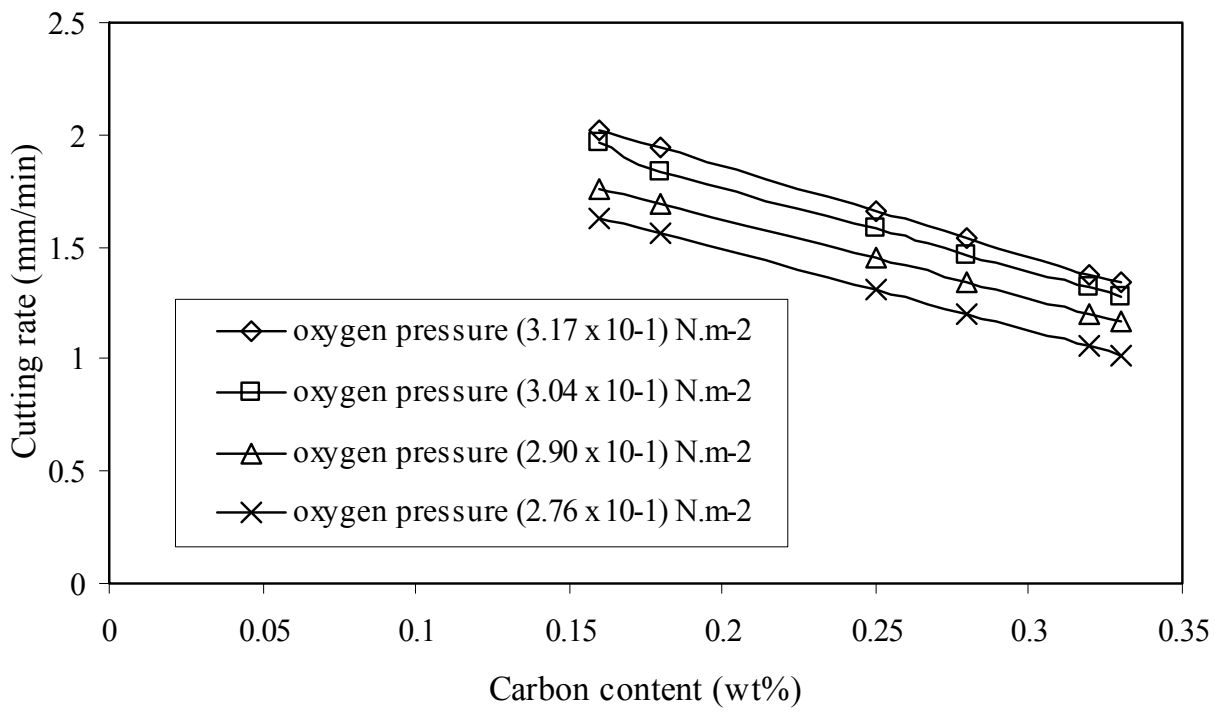

Figure 1: Variation of cutting rates with carbon content at $5.52 \times 10^{-2} \mathrm{~N} \cdot \mathrm{m}^{-2}$ acetylene pressure.

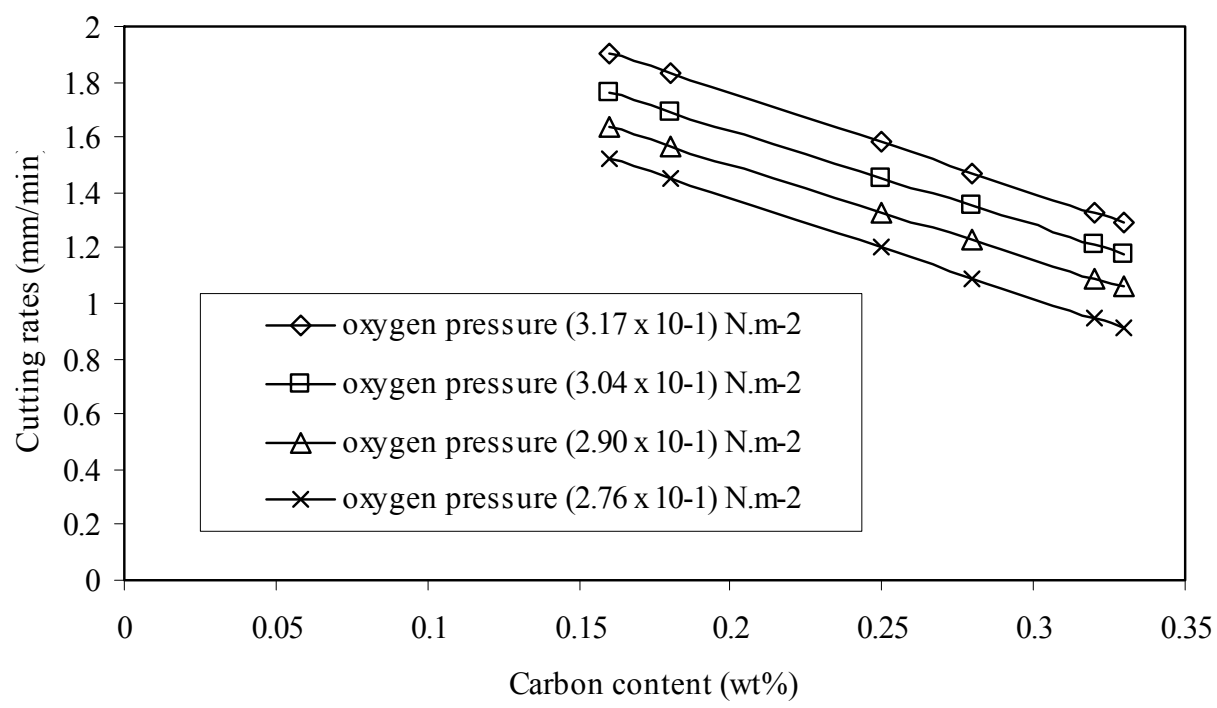

Figure 2: Variation of cutting rates with carbon content at $4.83 \times 10^{-2} \mathrm{~N} \cdot \mathrm{m}^{-2}$ acetylene pressure. 


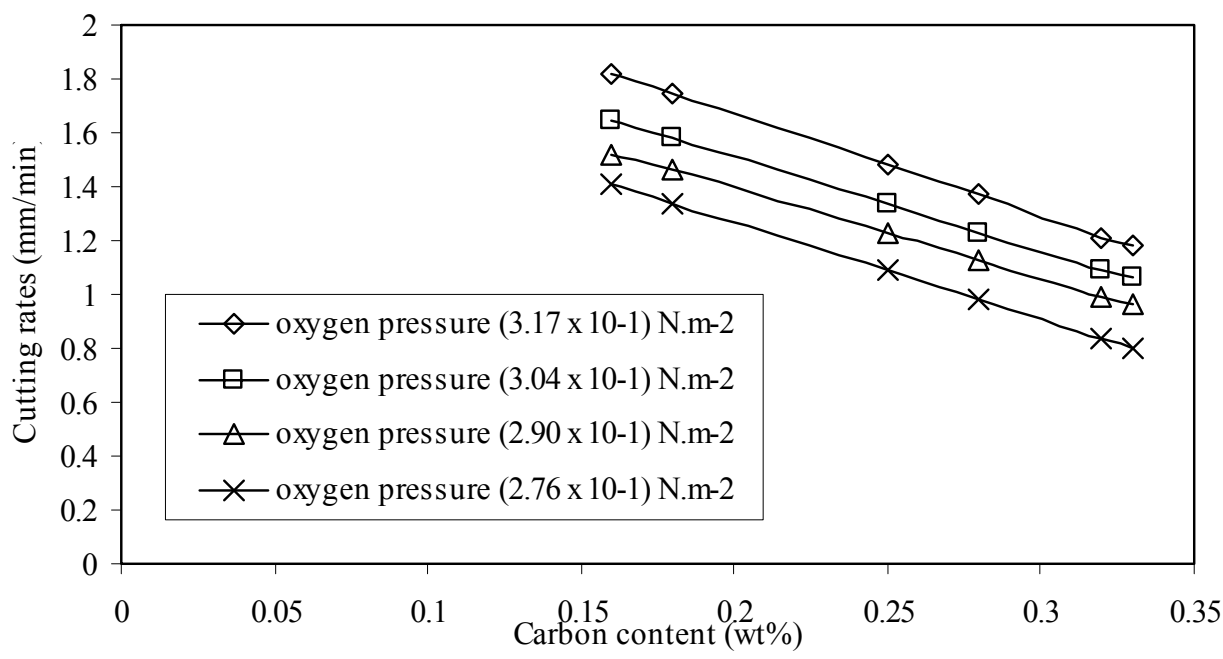

Figure 3: Variation of cutting rates with carbon content at $4.14 \times 10^{-2} \mathrm{~N} \cdot \mathrm{m}^{-2}$ acetylene pressure.

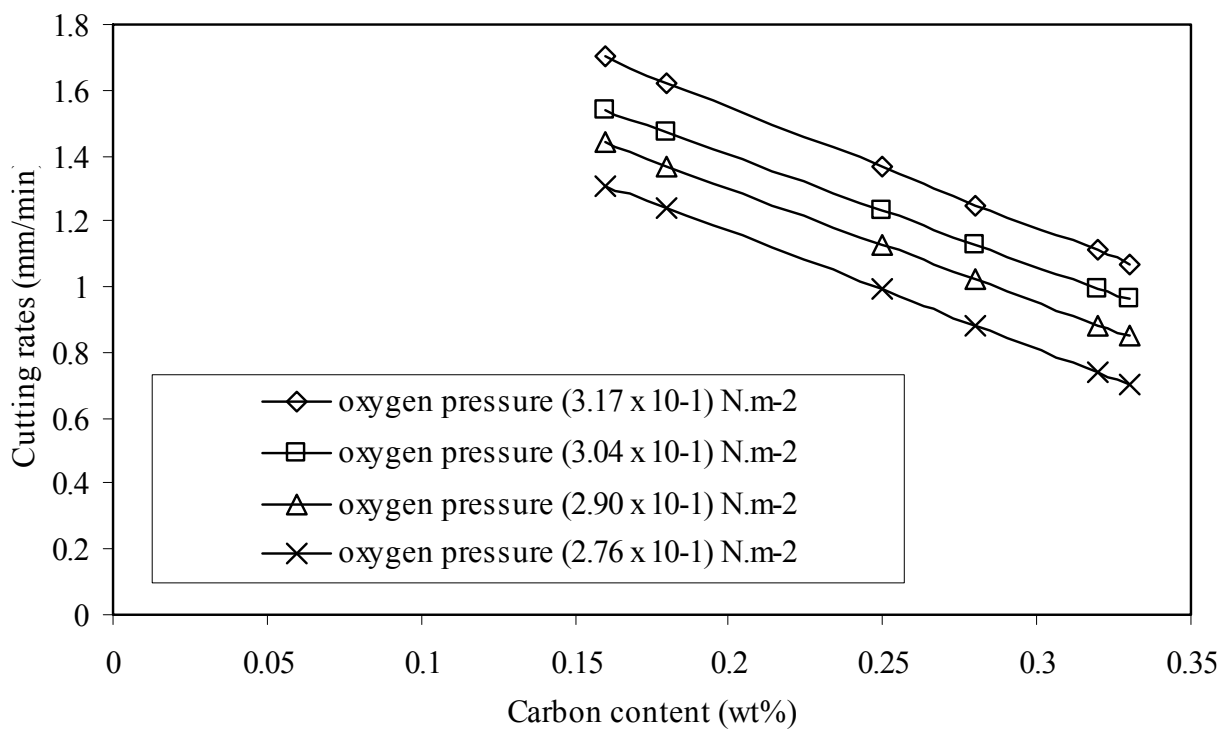

Figure 4: Variation of cutting rates with carbon content at $3.45 \times 10^{-2} \mathrm{~N} \cdot \mathrm{m}^{-2}$ acetylene pressure.

\subsection{Metal Oxidation Process}

Generally, during hot rolling process, an oxide scale layer always develops at the metal surface. Oxidation of steel at temperatures higher than $843 \mathrm{~K}$ leads to three different iron oxide layers: wustite $(\mathrm{FeO})$, magnetite $\left(\mathrm{Fe}_{3} \mathrm{O}_{4}\right)$ and hematite $\left(\mathrm{Fe}_{2} \mathrm{O}_{3}\right)$, in oxygen content increasing order, going from substrate to free surface. Below $843 \mathrm{~K}$, only the last two are thermodynamically stable [16]. According to the literature, the relative thickness fractions of 
these layers between $973 \mathrm{~K}$ and $1473 \mathrm{~K}$ are $95 \%$ wustite, $4 \%$ magnetite and $1 \%$ hematite at equilibrium $[16,17]$, although this balance can vary from one case to another. Depending on temperature, time, atmosphere conditions and steel chemistry, energy barriers develop, which must be overcome for an oxide to grow [16].

Kinetics of oxidation reactions of metals at high temperatures, are generally assumed to be controlled by the rates of mass transport of reactants and products in the gas-slag interface, slag-metal interface and slag phases [18]. The passage of oxygen from the gaseous phase through the slag to the metal is generally believed to be as illustrated below Fig. 5 and 6 .

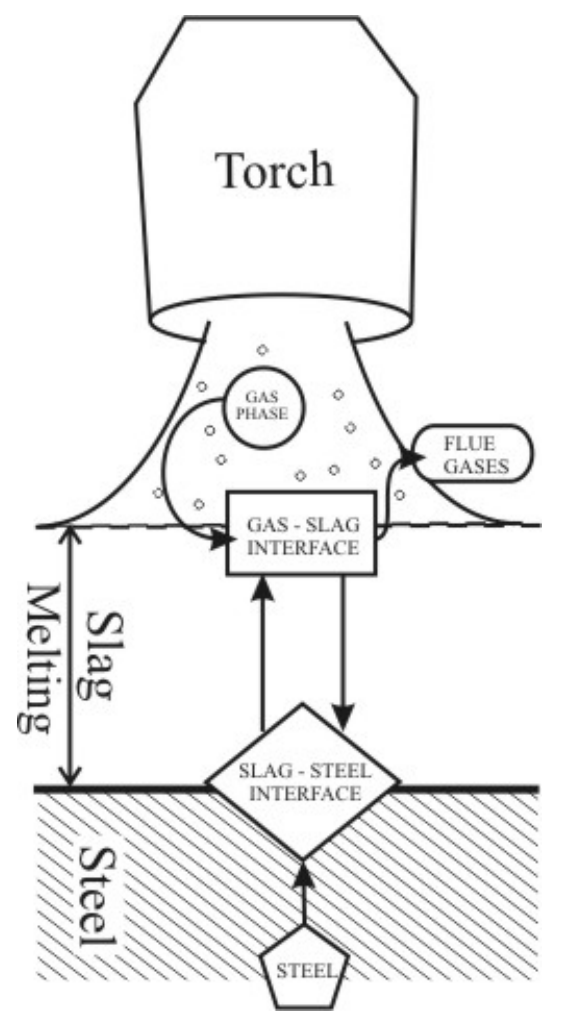

Figure 5: $\quad$ Pattern of interactions during flame cutting 




Figure 6: Reactions of slag forming process

However, Schwerdtfeger and Prange [19] have shown that slag-metal reactions involving iron and/or silicon under industrial process conditions are very unlikely controlled by the transfer kinetics of the reaction. Besides, whatever the means oxidation is being achieved, cutting by OFC-A is achieved by melting of the slag. The cutting rate in OFC-A will depend significantly on the rate of slag formation. Any reaction that retards formation of slag affects the cutting rate. $\mathrm{FeO}$ is a significant proportion of products of oxidation. When ferrous metals are cut by OFC-A, the process becomes one of rapid oxidation i.e. burning $[1,3,5,20]$. The retardation to the formation of $\mathrm{FeO}$ affects the cutting rate. Reactions below (equations 12 to 14) are unfavourable to the formation of $\mathrm{FeO}$.

$$
\begin{aligned}
& \mathrm{FeO}+\mathrm{C} \rightarrow \mathrm{Fe}+\mathrm{CO} \\
& \mathrm{FeO}+\mathrm{CO} \rightarrow \mathrm{Fe}+\mathrm{CO}_{2} \\
& \mathrm{CO}_{2}+\mathrm{C} \rightarrow 2 \mathrm{CO}
\end{aligned}
$$


Min et al [21] and Kudrin [22] confirm reaction between iron oxide (FeO) and carbon (C), while Min and Freuhan [23], Dogan [24] and Mori [18] elucidated on the reactions between iron oxide and carbon monoxide (CO), carbon monoxide and carbon.

Generally, high carbon steels are more difficult to flame cut because of the reactions between carbon, carbon monoxide and iron oxide [5, 25].

\subsection{Thermodynamics of OFC-A of Steels}

The general equation used to calculate $\Delta \mathrm{G}$ (the change in Gibbs free energy) is :

$$
\Delta G=\Delta H-T \Delta S
$$

where $\Delta \mathrm{H}$ is the enthalpy, i.e. the heat energy evolved by the reaction, $\mathrm{T}$ is the temperature in $\mathrm{K}$ and $\Delta \mathrm{S}$ is the change in entropy. Equation (15) above shows the temperature dependence of $\Delta \mathrm{G}, \Delta \mathrm{H}$ is also temperature dependent, as shown in the equation below:

$$
\Delta H_{T 2}=\Delta H_{T 1}+\int_{T 1}^{T 2} C_{p} d T
$$

where $C_{p}$ is the specific heat capacity at constant pressure.

During OFC-A, cutting flame only heats the metal to start the process; further heat is provided by the burning metal. It is generally agreed that the exothermic reaction of oxygen with the cut metal provides a considerable thermal input. The maximum reaction temperature of the process will consist of the sum of the heat by the flame and that of the exothermic reaction of oxygen with the cut metal. The steel flame cutting process consists of reactions as follows:

$$
\begin{array}{lr}
\mathrm{Fe}+1 / 2 \mathrm{O}_{2} \rightarrow \mathrm{FeO} & \Delta \mathrm{H}_{1}=\mathrm{q}_{1} \\
{[\mathrm{C}]+2[\mathrm{O}] \rightarrow \mathrm{CO}_{2}} & \Delta \mathrm{H}_{2}=\mathrm{q}_{2} \\
{[\mathrm{C}]+[\mathrm{O}] \rightarrow \mathrm{CO}} & \Delta \mathrm{H}_{3}=\mathrm{q}_{3}
\end{array}
$$

While the heat by the flame is expressed as:

$$
\begin{array}{ll}
\mathrm{C}_{2} \mathrm{H}_{2}+\mathrm{O}_{2} \rightarrow 2 \mathrm{CO}+\mathrm{H}_{2} & \Delta \mathrm{H}_{4}=\mathrm{q}_{4} \\
4 \mathrm{CO}+2 / 3 \mathrm{H}_{2}+\mathrm{O}_{2} \rightarrow 4 / 3 \mathrm{CO}_{2}+2 / 3 \mathrm{H}_{2} \mathrm{O} & \Delta \mathrm{H}_{5}=\mathrm{q}_{5}
\end{array}
$$

The total heat liberated by the OFC-A process of steel is given as the sum of heat of equations (17), (18), (19) and those of equations (20) and (21). The maximum heat input is given as: 


$$
\mathrm{Q}=\mathrm{q}_{1}+\mathrm{q}_{2}+\mathrm{q}_{3}+\mathrm{q}_{4}+\mathrm{q}_{5}
$$

The relationship between the maximum heat input and maximum reaction temperature $\left(T_{m}\right)$ is expressed thus:

$$
\mathrm{Q}=\int_{298}^{T_{m}} \sum n_{i} C_{p(\text { product })} d T
$$

Where $\mathrm{Cp}$ is the specific heat capacity of products at constant pressure, $\mathrm{n}_{\mathrm{i}}$ is the mole fractions of component $\mathrm{i}$ in the product. Thus;

$$
\mathrm{Q}=\int_{298}^{T_{m}}\left(n_{\mathrm{FeO}} \cdot C_{p(\mathrm{FeO})} \cdot d T+n_{\mathrm{CO}_{2}} \cdot C_{p\left(\mathrm{CO}_{2}\right)} \cdot d T+n_{\mathrm{CO}} C_{p(\mathrm{CO})} d T+n_{\mathrm{H}_{2}} C_{p\left(\mathrm{H}_{2}\right)} d T+n_{\mathrm{H}_{2} \mathrm{O}} C_{p\left(\mathrm{H}_{2} \mathrm{O}\right)} d T\right)
$$

$\mathrm{C}_{\mathrm{p}(\mathrm{CO} 2)}=44.14+9.04 \times 10^{-3} \mathrm{~T}-8.58 \times 10^{5} \mathrm{~T}^{-2} \mathrm{~J} / \mathrm{K} / \mathrm{mol}$

$\mathrm{C}_{\mathrm{p}(\mathrm{CO})}=28.45+4.184 \times 10^{-3} \mathrm{~T}-0.46 \times 10^{5} \mathrm{~T}^{-2} \mathrm{~J} / \mathrm{K} / \mathrm{mol}$

$\mathrm{C}_{\mathrm{p}(\mathrm{H} 2 \mathrm{O})}=30.0+10.71 \times 10^{-3} \mathrm{~T}-0.33 \times 10^{5} \mathrm{~T}^{-2} \mathrm{~J} / \mathrm{K} / \mathrm{mol}$

$\mathrm{C}_{\mathrm{p}(\mathrm{H} 2)}=15.02+6.09 \times 10^{-3} \mathrm{~T}-1.2 \times 10^{5} \mathrm{~T}^{-2} \mathrm{~J} / \mathrm{K} / \mathrm{mol}$

$\mathrm{C}_{\mathrm{p}(\mathrm{FeO})}=43.18+6.86 \times 10^{-3} \mathrm{~T}-1.15 \times 10^{5} \mathrm{~T}^{-2} \mathrm{~J} / \mathrm{K} / \mathrm{mol}$

The total value of $\mathrm{Q}$ depends on the ratios of $\mathrm{n}_{\mathrm{FeO}}: \mathrm{n}_{\mathrm{CO} 2}: \mathrm{n}_{\mathrm{CO}}$. This ratio is a function of concentration and activity of carbon and oxygen. Kudrin [22] and Bigeyev [27] showed that there is increased tendency for formation of carbon dioxide at lower carbon concentrations. Since $\mathrm{C}_{\mathrm{p}(\mathrm{CO} 2)}$ is about twice the value of $\mathrm{C}_{\mathrm{p}(\mathrm{CO})}$, higher values of $\mathrm{n}_{\mathrm{CO} 2}: \mathrm{n}_{\mathrm{CO}}$ will give higher heat input. Also, cutting rate has been shown to increase with temperature [4]. This is illustrated in Fig. 4. The energy available as heat from the $\mathrm{FeO}$ oxidation reaction at atmospheric pressure suddenly rises in energy evolved above the boiling point of iron $\left(\mathrm{T}_{\mathrm{b}}\right.$; $3330 \mathrm{~K}$ ). The reactions extinct at the dissociation temperature $T_{d}$ which is $3660 \mathrm{~K}$ (see Fig 5). 


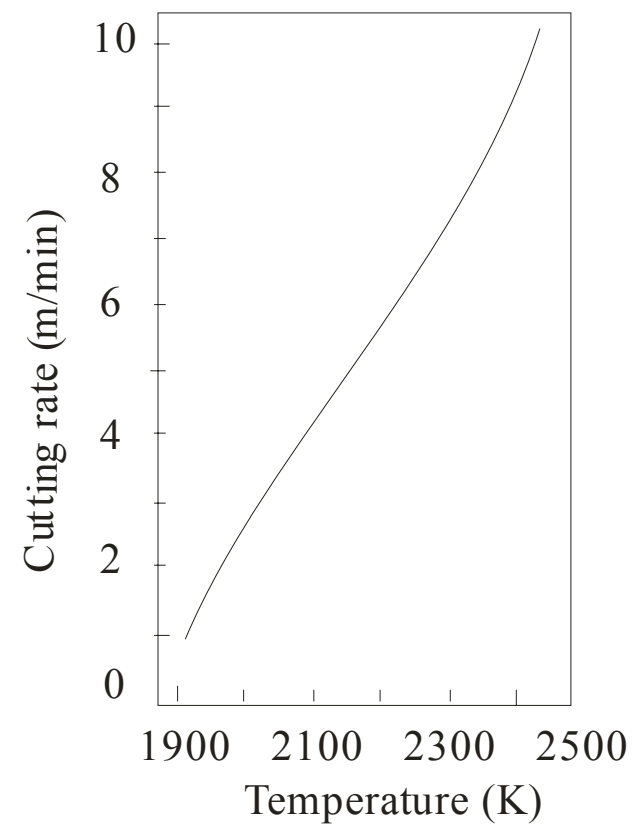

Figure 7: A typical relationship between cut front temperature and cutting rate $[4,27]$.



Figure 8: Variation of enthalpy and Gibbs free energy with temperature for $\mathrm{FeO}$ oxidation reaction at atmospheric pressure [4]. 
Although the thermal energy generated by the oxidation reaction rises by approximately $350 \mathrm{~kJ} / \mathrm{mol}$ (from 250 to 600 ) at the onset of boiling[4], the latent heat of boiling iron (347 $\mathrm{kJ} / \mathrm{mol}$ ) almost exactly matches this rise. Thus, if there is no increase in the proportion of iron oxidized there will be no net increase to the thermal input to the cutting process. The decarburization process retards iron oxidation, thereby reducing the proportion of iron oxidized per time. Generally, high carbon steels are more difficult to flame cut because of the reactions between carbon, carbon monoxide and iron oxide [5, 25].

\section{CONCLUSION}

Generally, the cutting rates decreased with carbon content of the steel. At the same oxygen pressure, cutting rates have decreased up till about 65 pct with increase in carbon content of about $0.17 \mathrm{wt} \%$. The reason for the observed trend being the retardation to the formation of $\mathrm{FeO}$ by decarburization reactions between iron oxide $(\mathrm{FeO})$ and carbon $(\mathrm{C})$, iron oxide and carbon monoxide $(\mathrm{CO})$, carbon monoxide and carbon.

\section{ACKNOWLEDGEMENT}

The author wishes to thank Dr John Powell of Lulea University of Technology. Lulea, Sweden and Nottingham University, Department of Mechanical, Materials and Manufacturing Engineering Nottingham, UK, for the help in providing relevant literatures during the preparation of the manuscript. The efforts of Engr. A.U. Ayinla and Mr Dare Amusa both of the Fabrication Unit, Institute of Technology, Kwara State Polytechnic, Ilorin, Nigeria is gratefully acknowledged.

\section{REFERENCES}

[1] American Welding Society 1997 American Welding Society welding Handbook, $8^{\text {th }}$ ed. New York

[2] Union Carbide Corp 1975 The Oxy-Acetylene Handbook, http://en.wikipedia.org/wiki/Oxy-fuel_welding_and_cutting\#cite_ref-The_OxyAcetylene_Handbook_1-4\#cite_ref-The_Oxy-Acetylene_Handbook_1-4

[3] DeGarmo, E.P.; Black, J.T.; Kosher, R.A. 1999 Material and Processes in Manufacturing $8^{\text {th }}$ ed. John Wiley and Sons, New York, pp 93

[4] Powell J, Petring D, Kumar R V, Al-Mashikhi S O, Kaplan A F H, Voisey K T 2009 Laser-oxygen cutting of mild steel: the thermodynamics of the oxidation reaction, $\mathrm{J}$. Phys. D: Appl. Phys. 42015504

[5] Masachuesset Institute of Technology, 2008, http://OCW.mit.edu/NR/rdonlyres/materials-science-and-engineering/3-051jspring

[6] Di Pietro, P., Yao, Y.L. 1995 A Numerical investigation into cutting front mobility in CO2 laser cutting. Int. J. Tools Manufact. 35673.

[7] Hsu, M.J., Molian, P.A. 1994 Thermochemical modelling in CO2 laser cutting of carbon steel. J. of Materials Science 295607. 
[8] Yilbas, B.S. 1996 Experimental investigation into $\mathrm{CO}_{2}$ laser cutting parameters. J. Materials Processing Technology 58323.

[9] Kaplan, A.F.H. 1996 An analytical model of metal cutting with a laser beam. J. Appl. Phys. 792198.

[10] Chen, K., Yao, Y.L., Modi, V. 1999 Numerical simulation of oxidation effects in the laser cutting process. Int. J. Adv. Manuf. Technol. 15835.

[11] Abdulhadi, E., Pelletier, J-M., Lambertin, M. 1997 Development in laser cutting of steel: analytical modelling and experimental validation of the metallurgical effects. SPIE 309717.

[12] Breaban, F., Entringer, P., Vantomme, P., Dard-Thuret, J., Rusaouen, G. 2006 Numerical Modelling of Laser Cutting Carbon Steel. Lasers in Eng.16 267.

[13] Ermolaev, G.V., Kovalev, O.B., Orishich, A.M., Fomin, V.M. 2006 Mathematical modelling of striation formation in oxygen laser cutting of mild steel. J. Phys. D: Appl. Phys. 394236.

[14] Li,L., Sobih, M., Crouse, P.L. 2007 Striation free laser cutting of mild steel sheets. Annals of the CIRP 56193.

[15] Sobih, M., Crouse, P.L., Li, L. 2008 Striation-free fibre laser cutting of mild steel sheets. J. Appl. Phys A. 90171.

[16] Suarez L., Coto R., Vanden-Eynde X., Lamberigts M., Houbaert Y., 2006 High Temperature Oxidation of Ultra-Low-Carbon SteelTrans Tech Publications, Switzerland Defect and Diffusion Forum Vols. 258-260 pp. 158-163, online at http://www.scientific.net

[17] Poirier D., Grandmaison E.W., Matovic M.D, Barnes K.R., Nelson B.D. 2006 High Temperature Oxidation of Steel in an Oxygen-enriched Low NOX Furnace Environment. IFRF Combustion Journal Article Number 200602, September 2006 ISSN 1562-479X, http://www.journal.ifrf.net/200602grandmaison.html

[18] Mori K. 1988 Kinetics of Fundamental Reactions Pertinent to Steelmaking Process, Transactions ISIJ, Vol. 28, pp 246-261.

[19] Schwerdtfeger G., Prange R. 1984 Exchange Current Densities for Slag-Metal Reactions. Proceedings of Second International Symposium Metallurgical Slags and Fluxes,ed. by H. A. Fine and D. R. Gaskell, RIME, New York, , 595.

[20] American Welding Society 1987 American Welding Society welding Handbook, $7^{\text {th }}$ ed. New York.

[21] Min D. J., Han J. W., Chung W. S. 1999 A Study of the Reduction Rate of FeO in Slag by Solid Carbon, Metallurgical and Materials Transaction B, Vol. 30, No. 2, pp. $215-221$.

[22] Kudrin, V. 1985 Steel Making, English translation, Mir publisher, Moscow, pp 72, 73, 76.

[23] Min D. J., Fruehan R. J. 1992 Rate of reduction of FeO in slag by Fe-C drops, Metallurgical and Materials Transactions B , Vol. 23, No.1, pp 29-37

[24] Dogan, N. 2009 Analysis of Droplet Generation in Oxygen Steelmaking. ISIJ International 49(1). 
[25] Higgins, R.A. 1993 Engineering metallurgy: Applied physical metallurgy, $6^{\text {th }}$ ed., Arnold. London, pp 499

[26] Bigeyev, A.M. 1977 Metallurgy of Steel, Metallurgiya, Moscow

[27] Miyamoto, I., Maruo, H. 1991 'The mechanism of laser cutting' Welding in the world. 29283. 